\title{
Purification of a Human Red Blood Cell Protein Supporting the Survival of Cultured CNS Neurons, and Its Identification as Catalase
}

\author{
Patricia Walicke, ${ }^{*}$ Silvio Varon, $\dagger$ and Marston Manthrope $\dagger$ \\ Departments of *Neurosciences and †Biology, School of Medicine, University of California, San Diego, La Jolla, \\ California 92093
}

\begin{abstract}
We have previously reported that red blood cells contain high levels of a protein that supports the survival of a variety of CNS neurons in vitro for $24 \mathrm{hr}$. Here we report the isolation of this trophic activity from human red blood cells. The active material, purified over 1000 -fold by ion-exchange chromatography and isoelectric focusing, has been identified as catalase based on its isoelectric point, subunit molecular weight, and ability to degrade hydrogen peroxide. Commercially produced bovine liver catalase, lactoperoxidase, $H R P$, and vitamin $E$ all mimic the ability of the purified human protein to support neuronal survival in vitro. Pharmacological inhibitors of peroxidase activity inhibit the trophic effects of both commercial catalase and the purified blood-derived protein. These results suggest that peroxidase activity mediates the neuronotrophic activity of these agents. The bioassay culture medium itself generates peroxides in the absence of cells. Removal of this toxic material may be the basis for the trophic effects of catalase.
\end{abstract}

Central nervous system neurons have been postulated to require specific neuronotrophic factors (Varon and Adler, 1981), in analogy to the well documented in vivo and in vitro requirement of sympathetic neurons for NGF (Greene and Shooter, 1980). The occurrence of developmental neuronal cell death in the CNS, as in the PNS, supports this hypothesis (Cowan et al., 1984). The similarity of responses of CNS and PNS neurons to axotomy, including morphological changes and cell death (Barron, 1983), provides further encouragement. Insufficient supplies of such neuronotrophic factors have been implicated in neuronal death after CNS trauma and in degenerative diseases (Appel, 1981; Varon et al., 1984a).

Because it allows manipulation of neurons in isolation from their normal cellular and environmental relationships, neuronal cell culture has played a key role in studies of NGF, and in the recognition and purification of new peripheral neuronotrophic factors, the chick eye and rat nerve ciliary neuronotrophic factors (CNTFs) (Barbin et al., 1984a; Manthorpe et al., 1985) and the pig brain-derived neurotrophic factor (BDNF) (Barde et al., 1982). Similar cultures of isolated CNS neurons have been developed and used to demonstrate the presence of trophic activity in tissue extracts, serum, and glial cell conditioned medium (Banker, 1980; Barbin et al., 1984b; Kaufman and Barrett, 1983; Manthorpe et al., 1982, 1983b; Rudge et al., 1985). Some of this trophic activity toward a variety of CNS neurons is due to the presence of low-molecular-weight molecules, such as py-

Received July 8, 1985; revised Sept. 25, 1985; accepted Sept. 25, 1985.

This work was supported by NSF Grant BNS 82-18366, American Paralysis Association Grant 83-10, and a grant from FIDIA Research Laboratories, Abano Terme, Italy.

Correspondence should be addressed to Dr. Walicke, Department of Neurosciences, M-008, School of Medicine, University of California, San Diego, La Jolla, CA 92093.

Copyright (C) 1986 Socicty for Ncuroscience $0270-6474 / 86 / 041114-08 \$ 02.00 / 0$ ruvate, rather than to proteins (Müller et al., 1984; Selak et al., 1985; Varon et al., 1984b). Cell culture methods have also allowed the detection of protein neuronotrophic factors affecting CNS neurons. Partially purified BDNF also supports retinal ganglion cell neurons (Turner, 1985), and a 55,000 molecular weight protein has been reported to promote spinal motor neuron survival (Gurney and Apatoff, 1984; Kaufman and Barrett, 1983). Fluids collected from aspiration wounds in the rat entorhinal cortex also contain neuronotrophic factors for spinal cord neurons that appear to be proteins based on ultrafiltration behavior, and heat and trypsin sensitivity (Manthorpe et al., 1983b; Nieto-Sampedro et al., 1982). A similar activity was also found in cerebrospinal fluid (CSF) samples from human head trauma paticnts, but not in CSF from uninjured paticnts (Longo et al., 1984). CNS-competent trophic activity was similarly present in blood, which inevitably contaminates samples from traumatized tissue and might have been responsible for the activity. Cellular fractionation of blood indicated that the activity was contained in red blood cells, rather than in plasma or platelets (Williams et al., 1985).

Here we describe the purification of the neuronotrophic protein from human hemolysate and its identification as catalase. The ability of the protein to support neuronal survival correlates closely with its peroxidase activity, and other molecules capable of degrading peroxide are also able to support neuronal survival. Cell culture sources of peroxide are discussed.

\section{Materials and Methods}

\section{Materials}

Bovine liver catalase (Cat. no. B-10), bovine milk lactoperoxidase (L8257), HRP (P8250), vitamin E (T3634), aminotriazole (A4383), and phenylhydrazine (P7126) were obtained from Sigma Chemical Co. Immobiline isoelectric focusing gel materials were obtained from LKB Bromma. Ion-exchange and analytical gel electrophoresis chemicals were obtained from various sources as described (Barbin et al., 1984a).

\section{Neuronal cell culture methods}

Assays were performed using cultures of embryonic day (E) 8 chick forcbrain ncurons, a heterogencous ccll population deriving from regions homologous with the mammalian striatum, thalamus, and cortex. Intact $\mathrm{E} 8 \mathrm{chick}$ forebrain was incubated for $30 \mathrm{~min}$ with $0.08 \%$ trypsin in calcium/magnesium-free balanced salt solution and then washed and triturated in Hank's modified Eagle's basal medium with $1 \%$ ovalbumin (Barbin et al., 1984b; Selak et al., 1985). Undissociated tissue was removed by filtration through a $40 \mu \mathrm{m}$ Nitex screen, and the cell concentration adjusted to $2 \times 10^{4}$ cells $/ \mathrm{ml}$. Aliquots $(50 \mu \mathrm{l})$ of the cell suspension were plated into 96 -well microtiter plates (Costar no. 3596) that had previously received $50 \mu \mathrm{l} /$ well of test medium for a final cell density of 1000 cells per $100 \mu \mathrm{l} /$ well. The substratum was polyornithine coated with schwannoma conditioned medium or purified laminin as previously described (Manthorpe et al., 1983a). All cultures were maintained in Hank's modified Eagle's basal medium, with additions of $2 \mathrm{~mm}$ glutamine, $100 \mathrm{U} / \mathrm{ml}$ penicillin, and the serum-free $\mathrm{N} 1$ supplement 
(containing $830 \mathrm{nM}$ insulin, $62.5 \mathrm{nM}$ transferrin, $100 \mu \mathrm{M}$ putrescine, 20 nM progesterone, and $30 \mathrm{nM}$ sodium selenite) (Barbin et al., 1984b; Bottenstein et al., 1980). After $24 \mathrm{hr}$, the cultures were fixed with glutaraldehyde, and surviving neurons counted in a strip covering $10 \%$ of the well area by phase microscopy. Less than $5 \%$ of the plated cells survived under control conditions, while $60-90 \%$ survived in supported cultures. Previous characterization of these cultures using immunologic cell markers demonstrated that non-neuronal cells (tetanus-toxin negative) constituted less than $10 \%$ of cells present (Barbin et al., 1984b); large flat cells were not counted in the determination of neuronal survival. Trophic activity was determined by finding the concentration supporting half-maximal neuronal survival in serial twofold dilutions, and is expressed in trophic units (TU) as previously described (Barbin et al., 1984b; also see Fig. 1).

\section{Preparation of hemolysate}

Outdated human packed red blood cells were obtained from a local blood bank. The cells were resuspended in an equal volume of PBS, pelleted by centrifugation at $2200 \times g$ for five min, and the supernatant and upper buffy coat portions discarded. This procedure was repeated twice, an equal volume of $10 \mathrm{~mm}$ phosphate buffer (pH 7.2) added, and the samples frozen. The thawed material, after addition of a second volume of phosphate buffer, was homogenized in a Waring blender at the highest speed for $2 \mathrm{~min}$ at $4^{\circ} \mathrm{C}$, centrifuged at $100,000 \times g$ for $1 \mathrm{hr}$, and the dark red supernatant collected. This procedure yielded about $400-500 \mathrm{ml}$ of a $33 \%$ red blood cell extract. The extract was dialyzed overnight against two changes of 14 liters of phosphate buffer. The resulting material was adjusted, if necessary, to $\mathrm{pH} 6.2$.

\section{DEAE chromatography}

Whatman DE-52 was prepared according to the manufacturer's instructions and equilibrated with $10 \mathrm{~mm}$ phosphate buffer $(\mathrm{pH} \mathrm{6.2)}$. A $1.7 \times$ $20 \mathrm{~cm}$ column, containing approximately $40 \mathrm{ml}$ bed volume of gel and eluted by gravity at a rate of $180-200 \mathrm{ml} / \mathrm{hr}$, was prepared. The hemolysate was applied to the column and the nonadsorbing material collected. Column flow rates decreased during this run to about $75 \mathrm{ml} /$ $\mathrm{hr}$, so that several hours were usually required. The nonadsorbing material from the first column was adjusted to $\mathrm{pH} 7.2$ with $1 \mathrm{~m} \mathrm{NaOH}$, and applied to a second identical DE-52 column adjusted to $\mathrm{pH} 7.2$. The loaded column was then washed with about $250 \mathrm{ml}$ of buffer and a $200 \mathrm{ml}$ linear gradient of $0.0-0.2 \mathrm{M} \mathrm{NaCl}$ in $10 \mathrm{~mm}$ buffer ( $\mathrm{pH} 7.2$ ) applied, followed by $100 \mathrm{ml}$ of $1 \mathrm{M} \mathrm{NaCl}$. Active fractions were determined by bioassay, pooled, and frozen at $-76^{\circ} \mathrm{C}$. Protein was assayed as described (Bradford, 1976) using BSA as a standard.

\section{Isoelectric focusing}

A preparative scale, $\mathrm{pH}$ 5.7-6.7 Immobiline isoelectric focusing gel, was prepared according to the manufacturer's instructions (LKB Bromma, Application Note 321$)$. A $5 \%$ acrylamide solution $(30 \mathrm{ml})$ containing appropriate concentrations of $\mathrm{pH} 3.6$ and 6.2 Immobilines were used to produce the desired pH 5.7 and 6.7 solutions, and glycerol was added to the acidic solution to increase its density. A silicone-coated gel mold with a backing of GelBond (FMC Corporation) was placed against one of the inner surfaces of two glass plates separated by a $6 \mathrm{~mm}$ spacer, and the acrylamide solution poured between the plates as a linear gradient from acidic to basic $\mathrm{pH}$. The gel was polymerized for $90 \mathrm{~min}$ at $50^{\circ} \mathrm{C}$, and washed in multiple changes of distilled water to remove the glycerol and unpolymerized materials. The gel was then dried back to its original weight using a fan. The gel was prefocused to remove impurities for $1 \mathrm{hr}$ at $4^{\circ} \mathrm{C}$ at a constant power of $5 \mathrm{~W}$.

Immobiline gels do not tolerate salt concentrations greater than 25 $\mathrm{mM}$ without distortion of focusing. Therefore, the pooled DEAE fractions were desalted by repeated concentration using an Amicon PM10 ultrafilter and the final volume adjusted to $20-30 \mathrm{ml}$ with $10 \mathrm{~mm}$ phosphate buffer

Desalted DEAE fractions were placed in a well (approximately $10 \times$ $2 \times 0.3 \mathrm{~cm}$ ) precast in the Immobiline gel, and focused at a constant power of $5 \mathrm{~W}$. The well could accommodate around 6-8 $\mathrm{ml}$ of sample, and a second 6-8 $\mathrm{ml}$ application was made after several hours, when the initial sample had entered the gel. Each gel could accommodate about half the DE-52 fraction.

After $24 \mathrm{hr}$, strips were cut from the edges of the gel and stained for four hours in Coomassie blue by the method of Blakesley and Boezi (1977). The remainder of the gel was kept under constant voltage during this period. The strips were then aligned with the body of the gel and regions of acrylamide containing the various bands and interspaces excised with a razor blade; strip thickness varied from 2 to $8 \mathrm{~mm}$. Each gel strip was eluted overnight at $4^{\circ} \mathrm{C}$ into $4 \mathrm{ml}$ of PBS containing $0.1 \%$ Triton X-100. Active fractions were identified by neuronal bioassay and pooled.

\section{$S D S-P A G E$}

Samples were prepared by overnight incubation at $37^{\circ} \mathrm{C}$ in $60 \mathrm{~mm}$ Tris$\mathrm{HCl}(\mathrm{pH} 6.8$ ) plus $2.3 \%$ SDS and 5\% mercaptoethanol. All gels were $7.5-20 \%$ acrylamide gradients with a $4.5 \%$ stacking gel. Methods of gel preparation, electrophoresis, and gel staining were performed as previously described (Barbin et al., 1984a).

\section{Catalase assay}

Catalase activity was assayed by a modification of a previously reported method (Brannan et al., 1981). The sample was preincubated for 10 min at $4^{\circ} \mathrm{C}$ in $0.5 \mathrm{ml} 10 \mathrm{~mm}$ phosphate buffer $(\mathrm{pH} 7.0)$ and $0.2 \mathrm{M}$ ethanol. One milliliter of $1.5 \mathrm{~mm}$ hydrogen peroxide $\left(\mathrm{H}_{2} \mathrm{O}_{2}\right)$ was added and the samples incubated for $10 \mathrm{~min}$ at $4^{\circ} \mathrm{C}$. The reaction was terminated by addition of $2 \mathrm{ml}$ of a mixture of $0.1 \mathrm{mg} / \mathrm{ml} \mathrm{HRP}$ and $0.1 \mathrm{~mm}$ dimethoxybenzidine. Optical densities were determined at $420 \mathrm{~nm}$. Catalasespecific activity (in $\mathrm{U} / \mathrm{mg}$ ) was calculated as $\left[\ln \left(A_{0}-A_{\mathrm{bl}} / A_{\mathrm{t}}-A_{\mathrm{b}}\right)\right](1 / \mathrm{mg}$ protein) $(1 / 10 \mathrm{~min})$, where $A_{0}$ is absorbance in the presence of $1 \mathrm{~mm}$ sodium azide, $A_{\mathrm{b} 1}$ is absorbance of sample and reagents without hydrogen peroxide, and $A_{1}$ is absorbance at $10 \mathrm{~min}$.

\section{Determination of peroxide concentrations in cell culture medium}

Medium was aspirated from the culture dishes and frozen until assay. The assay method was as described (Wang and Nixon, 1978). The thawed medium $(0.1 \mathrm{ml})$ was combined with $0.2 \mathrm{ml}$ of $0.05 \mathrm{M}$ acetic acid, $5 \mu \mathrm{l}$ of saturated ammonium molybdate, and $0.1 \mathrm{ml}$ of $15 \%$ potassium iodide. The optical density of the reaction product was determined at $360 \mathrm{~nm}$ and peroxide content (in $\mathrm{mM}$ ) derived by comparison with a standard curve of $\mathrm{H}_{2} \mathrm{O}$, added to fresh medium.

\section{Results}

\section{Fractionation of neuronotrophic activity}

An example of the titration curves used to calculate trophic titers by serial twofold dilution is shown in Figure 1. The 33\% human red blood cell lysate used as a starting material contains high concentrations of trophic material, on the order of $1-2 \times$ $10^{6} \mathrm{TU} / \mathrm{ml}$. There was no evidence of toxicity at dilutions of only 1:10 (i.e., $10^{5} \mathrm{TU} / \mathrm{ml}$ ); at lower dilutions hemoglobin deposits interfered with visualization of individual neurons. The morphology of embryonic forebrain neurons was not visibly different over the range of hemolysate concentrations supporting survival (data not shown). About $60-90 \%$ of seeded neurons were supported by the trophic activity in hemolysate. The level of the plateau and slopes of the regression are comparable to those previously reported for rat red blood cell extract (Williams et al., 1985).

The purification process is summarized in Table 1 . The first step in the purification of the trophic activity consisted of applying the hemolysate to a DEAE-cellulose column at $\mathrm{pH} 6.2$ and collection of the trophic activity in the nonadsorbed fraction. This resulted in only a minor degree of purification of the neuronotrophic activity, but was useful for removing some proteins that otherwise migrated near the active material during the subsequent isolectric focusing step (data not shown).

The nonadsorbed material from this first DEAE column was adjusted to $\mathrm{pH} 7.2$ and passed over a second, similar column. The results are shown in Figure $2 A$. At this higher $\mathrm{pH}$, most of the trophic activity bound to the column, while hemoglobin, accounting for over $90 \%$ of the hemolysate protein, did not bind. The bound trophic material eluted with a linear salt gradient at about $0.035 \mathrm{M} \mathrm{NaCl}$ and was contained in two fractions preceding the major protein peak. Further elution with $1 \mathrm{M} \mathrm{NaCl}$ 


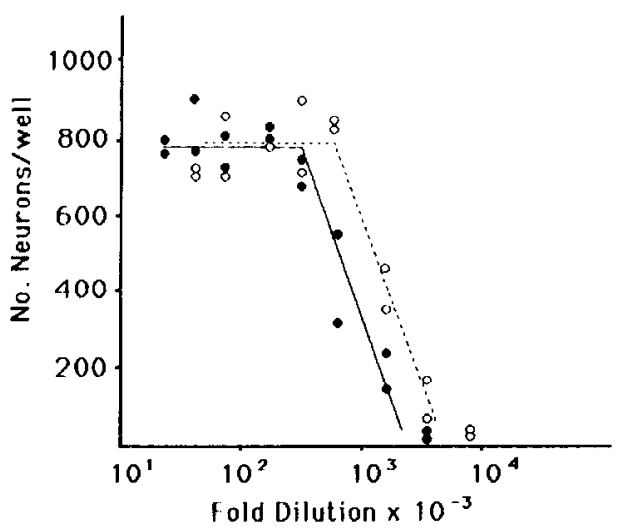

Figure 1. Dose-response curves for human CNS-directed neuronotrophic activities. Microwells were first provided with $50 \mu \mathrm{l}$ serial twofold dilutions of red blood cell lysate or a pooled fraction derived from isoelectric focusing gels. About 1000 embryonic chick forebrain neurons in $50 \mu \mathrm{l}$ were then added to each well, cultured for $24 \mathrm{hr}$, fixed with glutaraldehyde, and the number of surviving neurons determined by phase-contrast microscopy. One trophic unit per milliliter of a given sample is read directly as the dilution eliciting a half-maximal response and is, for the hemolysate $(0)$ and immobiline pool $(0)$ samples, respectively, about 800 and $1600 \mathrm{TU} / \mathrm{ml}$.

removed additional protein but no trophic activity. The active fractions were yellow-brown in color and exhibited $410 \mathrm{~nm}$ absorbance, charactcristic of heme groups (data not shown).

The two most active fractions (arrow bar in Fig. $2 A$ ) from this second DEAE column were pooled, desalted, concentrated, and submitted to preparative scale gel isoelectric focusing, as described in Materials and Methods. The focused gel was cut into slices and eluted in Triton X-100 in PBS; the eluates were assayed for CNS neuronotrophic activity and protein. The results are shown in Figure $2 B$. Nearly all the recoverable activity eluted from the pH 6.5-6.6 area (arrow bar in Fig. 2B) within a $5 \mathrm{~mm}$ region and separated from most of the recoverable protein. This purified material still exhibited a slightly yellowish color. The observed isoelectric point varied with the age of the DEAE preparation tested. Material that had been stored for several months displayed a more complex pattern with three to four peaks between $\mathrm{pH} 6.0$ and 6.6 (data not shown).

A comparison of trophic activity and protein yields within the hemolysate and the pooled derivative fractions from each major step is shown in Table 1. The progression of the purification is also illustrated by SDS-PAGE of the samples from each step (Fig. 3). The final step (isoelectric focusing) of the purification procedure yielded a fraction containing $14 \times 10^{6}$ TU (2.5\% of original hemolysate trophic activity) and $1.4 \mathrm{mg}$ protein, with a specific activity of $10^{7} \mathrm{TU} / \mathrm{mg}$, about 1200 -fold higher than the starting material. This final fraction (called "RBC

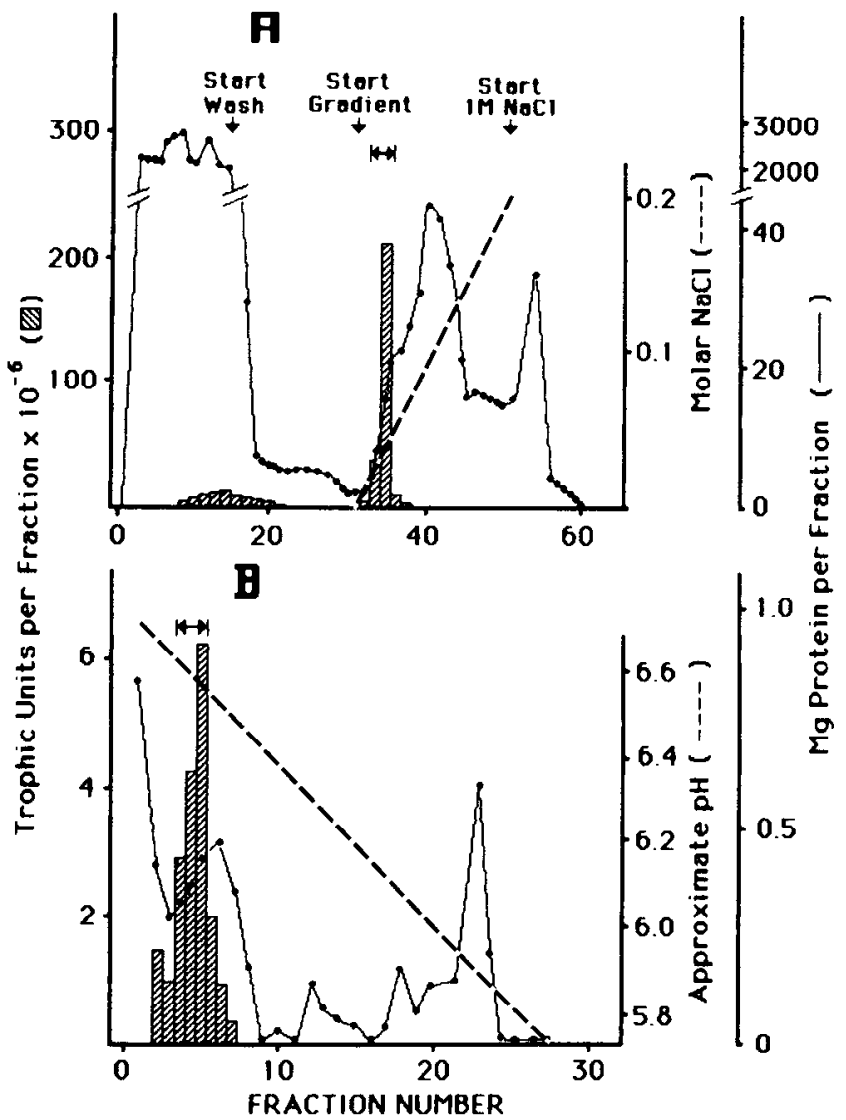

Figure 2. Fractionation of human CNS-directed neuronotrophic activity. $A$, Ion exchange (pH 7.2). Red blood cell extract $(450 \mathrm{ml})$ was prepared at $\mathrm{pH} 6.2$, passed through a DEAE column, the eluate pool adjusted to pH 7.2 and then submitted to a second DEAE column. Each fraction was assayed for protein and neuronotrophic activity; fraction sizes were $16.5 \mathrm{ml}$ for eluate, $10 \mathrm{ml}$ for gradient, and $1 \mathrm{M} \mathrm{NaCl}$. A substantial portion of the recoverable trophic units (histogram) was eluted in two fractions with about $0.035 \mathrm{M} \mathrm{NaCl}$ (dashed line) and separated from most of the recovered protein (solid lines). $B$, Isoelectric focusing (pH 5.7-6.7). One-half of the salt-eluted pool (arrow bar) was submitted to polyacrylamide gel isoelectric focusing over a very narrow pH range (5.7-6.7). Slices were taken over the length of the focused gel, eluted, and assayed for protein and trophic activity (see Materials and Methods). Most of the recovered activity (histogram) focused in the pH 6.5-6.6 region and separated from most of the protein (solid lines).

trophic protein") exhibits one $60 \mathrm{kDa}$ Coomassie blue-stained band after SDS-PAGE (Fig. 3, lane 4) but exhibits additional minor bands when a more sensitive silver stain is used (Fig. 4, lane 1).

Table 1. Purification of human red blood cell-derived neuronotrophic activity for CNS neurons

\begin{tabular}{lcccrrrr} 
Fraction & $\mathrm{ml}$ & \multicolumn{2}{c}{$\begin{array}{l}\mathrm{TU} \\
\times 10^{-6}\end{array}$} & $\begin{array}{l}\text { Protein } \\
(\mathrm{mg})\end{array}$ & $\begin{array}{l}\text { TU/mg } \\
\times 10^{-3}\end{array}$ & $\begin{array}{l}\text { Increase } \\
(n \text {-fold })\end{array}$ & \multicolumn{2}{c}{ Recovery (\%) } \\
\hline Hemolysate & 450 & 560 & 67,000 & 8 & 1 & 100 & 100 \\
DEAE, pH 6.2 cluatc & 450 & 460 & 45,000 & 10 & 1.2 & 82 & 67 \\
$\begin{array}{l}\text { DEAE, pH 7.2 pool } \\
\text { Isoelectric focusing pool }\end{array}$ & 28 & 220 & 50 & 4400 & 550 & 39 & 0.075 \\
$\quad$ ("RBC trophic protein") & 16 & 14 & 1.4 & 10,000 & 1200 & 2.5 & 0.002
\end{tabular}

Fractions were prepared and assayed for trophic units (TU) and protein (mg), as described in Materials and Methods. Values are averages of duplicate determinations for each of four separate bioassays of fractions from one representative purification run 


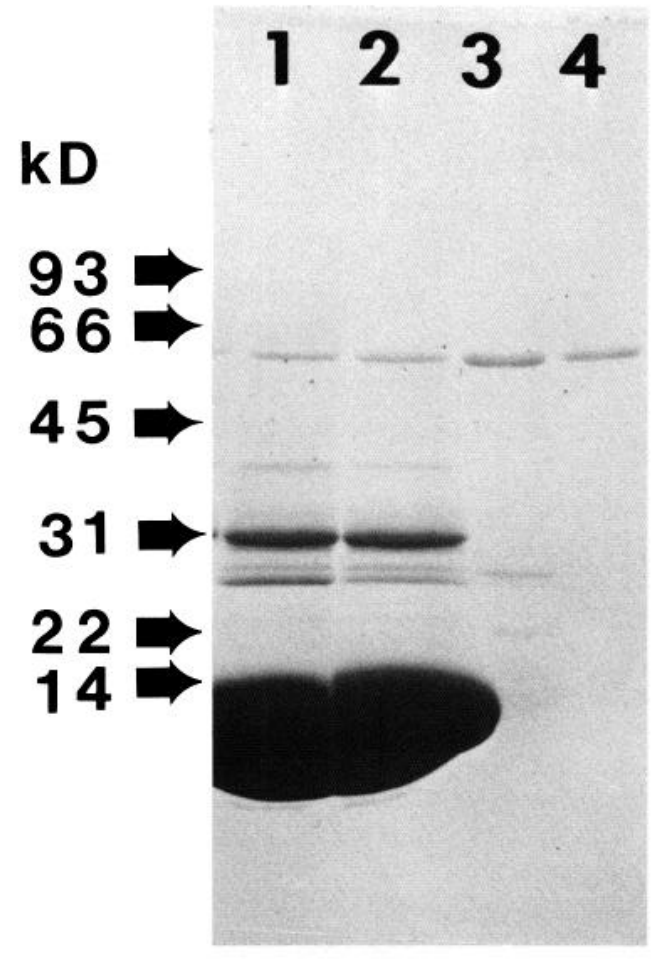

Figure 3. SDS-PAGE of selected fractions generated during the purification of the human $\mathrm{RBC}$ trophic protein. Lanes 1 and 2 were loaded with $2.5 \times 10^{4} \mathrm{TU}$, and lanes 3 and 4 with $5 \times 10^{4} \mathrm{TU}$. The lanes correspond to each of the four fractions shown in Table 1, as follows: Lane 1, hemolysate; lane 2, pH 6.2 DEAE eluate; lane 3, pH 7.2 DEAE pool; and lane 4, isoelectric focusing pool ("RBC trophic protein"). The gel was stained with Coomassie blue. Molecular weight markers were phosphorylase b $(93 \mathrm{kDa})$, BSA $(66 \mathrm{kDa})$, ovalbumin $(45 \mathrm{kDa})$, carbonic anhydrase $(31 \mathrm{kDa})$, soybean trypsin inhibitor $(22 \mathrm{kDa})$, and lysozyme $(14 \mathrm{kDa})$.

We failed in numerous attempts to elute detectable neuronotrophic activity from SDS-PAGE gels, even after application of $10^{7} \mathrm{TU} /$ lane. Simply incubating the RBC trophic protein with the SDS and mercaptoethanol electrophoresis buffer irreversibly destroyed its activity. Attempts to reconstitute the activity by SDS removal (dialysis, $8 \mathrm{~m}$ urea, hydrophobic interaction chromatography or incubation with protein and buffer) were unsuccessful. Therefore, indirect methods were employed to determine whether the $60 \mathrm{kDa}$ band represented the trophic activity. The $\mathrm{pH}$ 7.2 DEAE pool (Table 1) was submitted to (1) sucrose density gradient centrifugation according to Barbin et al. (1984a), (2) hydrophobic affinity chromatography using 2-12 carbon side chains (Shaltiel, 1974), and (3) cibacron blue, procion red, green $\mathrm{A}$, orange $\mathrm{A}$, and blue $\mathrm{B}$ dye affinity chromatography (Amicon Corporation, 1980; Porumb et al., 1982) and the trophic activity monitored by bioassay. After each fractionation protocol, the active fractions were pooled and submitted to analytical SDSPAGE. In all cases, the bioactive fractions, but not selected inactive fraction pools, displayed a prominent $60 \mathrm{kDa}$ band, accompanied by minor bands that tended to vary in their $M_{\mathrm{r}}$ value (data not shown). These observations support the contention that the RBC trophic activity resides with the $60 \mathrm{kDa}$ protein band exhibited after SDS-PAGE.

The purification and biochemical characterization described above indicated that the human RBC trophic protein (1) binds weakly to DEAE-cellulose at neutral pH; (2) may contain heme groups, as indicated by $410 \mathrm{~nm}$ absorbance; (3) has an isoelectric point of about 6.6, with appearance of more acidic forms after storage; (4) has a subunit molecular weight of $60 \mathrm{kDa}$ by SDS-
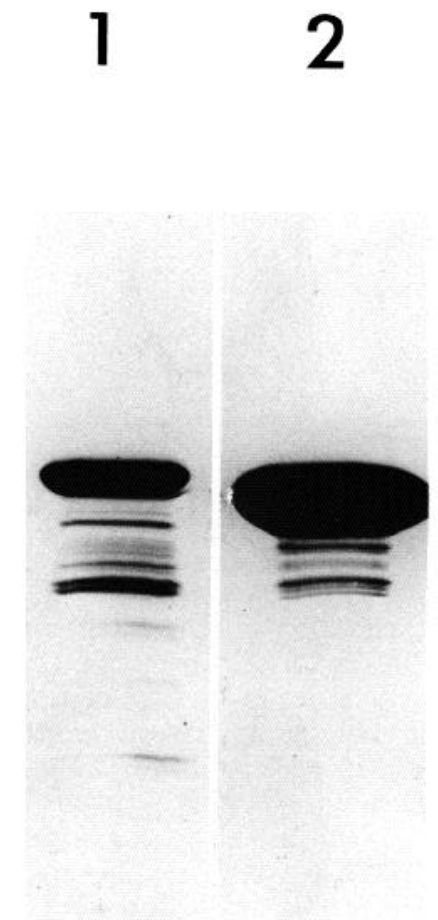

Figure 4. SDS-PAGE and silver staining of $50 \mu \mathrm{g}\left(5 \times 10^{s} \mathrm{TU}\right)$ of the purified human RBC trophic protein (lane $I)$ and $100 \mu \mathrm{g}\left(4 \times 10^{5} \mathrm{TU}\right)$ of bovine liver catalase (lane 2).

PAGE; and (5) is inactivated by dissociation into subunits with SDS and mercaptoethanol. An examination of the literature describing properties of previously purified $\mathrm{RBC}$ proteins revealed that the peroxide-degrading enzyme, catalase, shares with the RBC trophic protein all of the above properties (Aebi et al., 1974; Hennessey et al., 1962; Mörikofer-Zwez et al., 1969; Olofsson and Olsson, 1977; Porumb et al., 1982). Commercially available purified bovine liver catalase (purified human RBC catalase is not yet available commercially) exhibited a slightly faster migration on SDS gels than the RBC trophic protein (compare lanes 1 and 2, Fig. 4). Bovine catalase is composed of 506 amino acid residues/subunit compared to at least 520 residues/ subunit for the human RBC catalase (Schroeder et al., 1982).

If the purified $\mathrm{RBC}$ trophic protein is indeed catalase, then it follows that (1) it should possess catalase enzymatic activity, (2) catalase enzymatic activity should copurify with the trophic activity using the present procedure, and, conversely, (3) catalase from another source should possess trophic activity for $\mathrm{CNS}$ neurons.

Catalase enzymatic activity was monitored during the purification of the human RBC trophic protein, and beef liver catalase was tested for neuronotrophic activity. The results are shown in Table 2. The purified RBC trophic protein indeed possesses the ability to degrade $\mathrm{H}_{2} \mathrm{O}_{2}$, and this enzymatic ac- 
Table 2. Co-purification of neuronotrophic and catalase enzymatic activities

\begin{tabular}{lccccc} 
& $\begin{array}{l}\text { Trophic } \\
\text { activity } \\
(\mathrm{TU} / \mathrm{mg} \\
\left.\times 10^{-3}\right)\end{array}$ & $\begin{array}{l}\text { Increase } \\
(n \text {-fold })\end{array}$ & $\begin{array}{l}\text { Catalase } \\
\text { activity } \\
(\mathrm{U} / \mathrm{mg} \\
\left.\times 10^{-3}\right)\end{array}$ & $\begin{array}{l}\text { Increase } \\
(n \text {-fold })\end{array}$ & $\begin{array}{l}(\mathrm{TU} / \mathrm{mg}) / \\
(\mathrm{U} / \mathrm{mg})\end{array}$ \\
Fraction & 8 & 1 & 12 & 1 & 0.7 \\
\hline Hemolysate & 10 & 1.2 & 13 & 1.1 & 0.8 \\
$\begin{array}{l}\text { DEAE, pH 6.2 eluate } \\
\text { DEAE, pH 7.2 pool }\end{array}$ & 4400 & 550 & 4100 & 340 & 1.1 \\
$\begin{array}{l}\text { Isoelectric focusing pool } \\
\quad \text { ("RBC trophic protein") }\end{array}$ & 10,000 & 1200 & 12,000 & 1000 & 0.8 \\
Bovine liver catalase & 4200 & - & 4000 & - & 1.1
\end{tabular}

Fractions were generated and assayed for trophic units (TU), catalase units (U), and protein (mg), as described in Materials and Methods. Catalase activity values are averages of six determinations on a single set of fractions. Trophic activity and protein are as in Table 1.

tivity was enriched 1000 -fold during the purification protocol, compared to 1200 -fold for the trophic activity. Purified bovine liver catalase is a potent supporter of neuronal survival. Microscopic inspection of the catalase-supported cultures showed identical maximal number and morphology of surviving neurons compared to cultures supported by the RBC trophic protein (data not shown). The liver catalase possesses about half the trophic activity $\left(4.2 \times 10^{6} \mathrm{vs} 10^{\prime} \mathrm{TU} / \mathrm{mg}\right)$ and one-third the catalase activity $\left(4.0 \times 10^{6} \mathrm{vs} 12.2 \times 10^{6} \mathrm{TU} / \mathrm{mg}\right)$ of the human $\mathrm{RBC}$ trophic protein. A comparison of the ratio of trophic to catalase units reveals a relatively constant value $(0.7-1.1)$, further suggesting an identity between the two properties of $\mathrm{H}_{2} \mathrm{O}_{2}$ degradation and neuronal survival promotion.

\section{Identity of peroxidase activity and trophic activity of catalase}

The only known function of catalase is degradation of $\mathrm{H}_{2} \mathrm{O}_{2}$. However, it is possible that its apparent trophic activity could reflect novel attributes of the enzyme. Aminotriazole and phenylhydrazine are both irreversible irihibitors of catalase enzymatic activity, and both bind to a conformation of the enzyme that occurs during interaction with $\mathrm{H}_{2} \mathrm{O}_{2}$ (Ortiz de Montellano and Kerr, 1983; Sinet et al., 1980). Aminotriazole is considered

Table 3. Effects of catalase inhibitors on the neuronotrophic activity directed to CNS neurons

\begin{tabular}{|c|c|c|c|}
\hline \multirow[b]{2}{*}{ Fraction } & \multirow[b]{2}{*}{ Saline $^{a}$} & \multicolumn{2}{|c|}{ TU remaining with } \\
\hline & & $\begin{array}{l}\text { Amino- } \\
\text { triazole } \\
(\%)\end{array}$ & $\begin{array}{l}\text { Phenyl- } \\
\text { hydra- } \\
\text { zine }\end{array}$ \\
\hline \multicolumn{4}{|l|}{ Pretreatment } \\
\hline 1. Human RBC trophic protein & 100 & 4 & 4 \\
\hline 2. Bovine liver catalase & 100 & 18 & 4 \\
\hline 3. Human hemolysate & 100 & 10 & 15 \\
\hline 4. Rat hemolysate & 100 & 9 & 8 \\
\hline \multicolumn{4}{|l|}{ Inclusion in medium } \\
\hline 5. Human RBC trophic protein & 100 & 4 & 4 \\
\hline 6. Bovine liver catalase & 100 & 4 & 18 \\
\hline \multicolumn{4}{|c|}{$\begin{array}{l}\text { A } 100 \mu \mathrm{l} \text { aliquot of the indicated fraction was incubated for } 1 \mathrm{hr} \text { at } 37^{\circ} \mathrm{C} \text { with } 1 \\
\text { ml } 10^{-4} \mathrm{M} \mathrm{H} \mathrm{H}_{2} \mathrm{O}_{2} \text { in } 0.1 \% \text { Triton } \mathrm{X}-100 \text { PBS with or without } 40 \mathrm{~mm} \text { aminotriazole } \\
\text { or } 0.5 \mathrm{mM} \text { phenylhydrazine, dialyzed overnight at } 4^{\circ} \mathrm{C} \text { against Triton X-100 PBS } \\
\text { to remove toxic } \mathrm{H}_{2} \mathrm{O}_{2} \text { and inhibitors, and assayed for trophic activity (Pretreatment) } \\
\text { Recovery of units was } 80-100 \% \text { after incubation and dialysis in the absence o } \\
\text { enzymatic inhibitors. Alternatively, the two inhibitors were included in the hioassay } \\
\text { medium of the human } \mathrm{RBC} \text { trophic protein or catalase (Inclusion in medium), a } \\
5 \mathrm{~mm} \text { for aminotriazole or } 30 \mu \mathrm{M} \text { for phenylhydrazine. Concurrent cultures supported } \\
\text { by pyruvate showed these concentrations to be nontoxic. }\end{array}$} \\
\hline \multicolumn{4}{|c|}{$\begin{array}{l}\text { One hundred percent values in TU/ml were }(1 \text { and } 5) 4.7 \times 10^{5},(2 \text { and } 6) 8.0 \times \\
10^{5}, \text { (3) } 5.3 \times 10^{5} \text {, and (4) } 2.6 \times 10^{5} \text {. }\end{array}$} \\
\hline
\end{tabular}

to be a specific inhibitor of catalase. Although less specific, phenylhydrazine was also examined to provide verification of potential effects observed with aminotriazole. The two inhibitors of catalase enzymatic activity were tested for their effects on the trophic activity of the purified human RBC trophic protein and bovine liver catalase, as well as on crude hemolysates from human and rat. Samples were incubated in a solution of the appropriate inhibitor plus $\mathrm{H}_{2} \mathrm{O}_{2}$. Even at a dilution of $1: 10^{6}$, $\mathrm{H}_{2} \mathrm{O}_{2}$ was neurotoxic in the bioassay for neurons supported by pyruvate (Selak et al., 1985). However, dialysis of the samples overnight eliminated this toxicity, thus allowing detection of residual trophic activity. The results are shown in Table 3 . Both inhibitors reduced by at least $80 \%$ the trophic activities of both the purified RBC trophic protein and purified bovine catalase. Also, $85-90 \%$ of the trophic activity present within crude hemolysates was eliminated, suggesting that nearly all of the trophic units lost during purification (i.e., from Table 1 the $2.5 \% \mathrm{TU}$ yield indicates a loss of about $97.5 \%$ of the starting material) of the human RBC trophic protein may be attributable to catalase.

The effects of the catalase inhibitors were also examined directly in culture by adding either aminotriazole or phenylhydrazine to the bioassay medium. Both inhibitors had some toxicity (aminotriazole above $35 \mathrm{~mm}$ and phenylhydrazine above $1.2 \mathrm{~mm}$ ) when presented to the neurons in the presence of pyruvate. Concentrations below these toxic levels were tested with both bovine liver catalase and the human RBC trophic activity (Table 3, lines 5 and 6). Again, trophic activity was considerably reduced by the enzymatic inhibitors. Since the inhibitors only bind in the presence of $\mathrm{H}_{2} \mathrm{O}_{2}$, this finding suggests the presence of this material in the culture system (Sinet et al., 1980).

If peroxides are killing the neurons during the neuronotrophic bioassay and catalase is supporting neuronal survival through its pcroxidc-dcgrading enzymatic activity, then other methods

Table 4. Antiperoxidants have neuronotrophic activity toward CNS neurons

\begin{tabular}{lcl} 
Antiperoxidant & $\begin{array}{l}\text { TU/mg } \\
\left(\times 10^{-3}\right)\end{array}$ & $\begin{array}{l}\text { TU/peroxi- } \\
\text { dase (units } \\
\left.\times 10^{-3}\right)\end{array}$ \\
\hline Bovine liver catalase & 17,000 & 570 \\
Lactoperoxidase & 1000 & 570 \\
HRP & 1900 & 720 \\
Vitamin E & 0.4 & 200
\end{tabular}

The indicated commercially available antiperoxidant materials were tested for neuronotrophic activity and expressed in $\mathrm{TU} / \mathrm{mg}$ protein or $\mathrm{TU} / \mathrm{mg} \alpha$-tocopherol for vitamin E. Peroxidase units were derived from the manufacturers' specifications for the enzymes; international units (IU) are used for vitamin $\mathrm{E}$. 
of removing $\mathrm{H}_{2} \mathrm{O}_{2}$ should also support neuronal survival. Two commercially available antiperoxidant enzymes, lactoperoxidase and HRP, as well as the nonenzymatic antioxidant, vitamin $\mathrm{E}$, were therefore tested for neuronotrophic activity. The results are shown in Table 4 . Both enzymes and vitamin $E$ were, by themselves, able to support neuronal survival. Estimates of the specific peroxidase activity (provided by the manufacturers) were used to calculate the ratios of specific trophic activity and specific peroxidase activity. It should be noted that these assays yielded different units than the catalase units used in Table 3. The relative constancy of this ratio (between $570-720$ for the enzymes) again suggests that neuronotrophic and peroxidase activities are closely related, if not identical, properties.

These results also provide indirect support for the conclusion that catalase, rather than one of the impurities present in the RBC trophic protein preparation (see Fig. 4), represents the trophic activity. The various substances tested derive from very different sources (human blood, bovine liver or milk, radish root, and vegetable oil) and differ markedly in basic physicochemical properties such as size and isoelectric point (Bunt and Haschke, 1978; Malmgren et al., 1978; Nässel, 1983). Thus, it is highly unlikely that a common contaminant representing the trophic activity could be present in these different preparations.

\section{Presence of peroxides in the culture medium used for neuronotrophic bioassays}

If catalase promotes neuronal survival in vitro by removal of $\mathrm{H}_{2} \mathrm{O}_{2}$, then this cytotoxic material should be present within the cultures, and its levels should be reduced in the presence of catalase. To test these possibilities, neuronotrophic bioassay medium was incubated in microculture wells in the usual manner (see Materials and Methods) but without cells and with or without added catalase. At the indicated times the medium was removed and assayed for peroxide content in an assay that detects both $\mathrm{H}_{2} \mathrm{O}_{2}$ and organic peroxides. The results are shown in Figure 5. Two points are evident. First, peroxides accumulated in the culture medium to a concentration of about $40 \mathrm{~mm}$ between 4 and $12 \mathrm{hr}$ of incubation and remained at that level for an additional $12 \mathrm{hr}$. Second, exogenously added catalase substantially reduced, but did not eliminate, peroxide accumulation at all three times. These results demonstrate that the culture medium itself is a source of measurable peroxides, and raise the possibility that catalase is primarily affecting the neuronal environment rather than directly interacting with the neurons themselves.

\section{Discussion}

By a combination of ion-exchange chromatography and isoclectric focusing, a neuronotrophic protein previously detected in red blood cells has been purified over 1000 -fold. The final material possesses an activity of $10^{7} \mathrm{TU} / \mathrm{mg}$ protein, which means that half-maximal activity occurs at $100 \mathrm{pg} / \mathrm{ml}$, which compares favorably to the potency of other isolated trophic factors. This protein has been identified as catalase on the basis of its fractionation behavior on DEAE-cellulose columns; absorbance at $410 \mathrm{~nm}$, indicating the presence of a heme group; isoelectric point; subunit molecular weight determined by SDSPAGE; and its co-purification with peroxidase activity (Aebi et al., 1974; Hennessey et al., 1962; Mörikofer-Zwez et al., 1969; Olofsson and Olsson, 1977; Porumb et al., 1982; Schroeder et al., 1982). Furthermore, commercially prepared bovine liver catalase reproduces the effects of the purified human $\mathrm{RBC}$ trophic protein in supporting neuronal survival. Incubation of the RBC trophic protein in SDS and mercaptoethanol destroys its trophic activity, just as the dissociation of catalase into its subunits is recognized to disrupt enzymatic activity (Aebi et al., 1974). Two irreversible inhibitors of catalase enzymatic activity, aminotriazole and phenylhydrazine (Ortiz de Montellano and

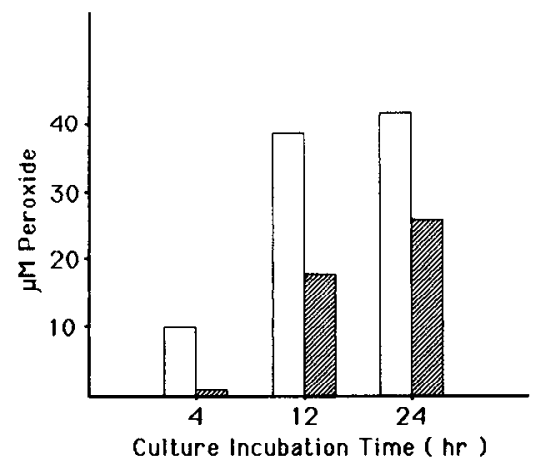

Figure 5. Catalase reduces spontaneous peroxide generation in neuronal culture medium. Aliquots of culture medium, $100 \mu \mathrm{l}$, were incubated in the absence of neurons but under standard neuronotrophic factor bioassay conditions (see Materials and Methods) in the absence (open histograms) or presence (hatched histograms) of $10^{3} \mathrm{TU}$ of human $\mathrm{RBC}$ catalase. At the indicated times, the medium was assayed for peroxide content (see Materials and Methods).

Kerr, 1983; Sinet et al., 1980), also block the ability of the RBC trophic protein and catalase to support the survival of cultured neurons. Besides catalase, two other peroxide-degrading enzymes, lactoperoxidase and HRP, are also potent supporters of neuronal survival. The ratio of trophic units to enzymatic units is quite similar for these three enzymes. In addition, vitamin E, a nonenzymatic antioxidant, can replace catalase as a trophic agent. Altogether, the above results not only demonstrate that the trophic material in hemolysates is catalase, but also justify the conclusion that catalase supports neuronal survival through its ability to degrade $\mathrm{H}_{2} \mathrm{O}_{2}$.

The effect of catalase in promoting the survival of cultured CNS neurons is not limited to those from chick forebrain. We previously reported (Longo et al., 1984; Williams et al., 1985) that hemolysates also support the survival of cultured $18 \mathrm{~d}$ fetal rat hippocampal, striatal, and septal neurons. The purified human catalase reported here, as well as the beef liver catalase, will also support all three rat neuronal types, as well as cortical neurons from the area $\mathrm{V}$ sensory motor region, at concentrations comparable to those required for chick forebrain neurons (data not shown). Although catalase has not been reported as a neuronotrophic agent, vitamin $E$ has previously been observed to enhance cortical neuron survival in reaggregate cultures (HalksMiller et al., 1982). Others have suggested that a variety of cultured non-neurcnal cells show increased survival in the presence of catalase, including lymphoma cells, Erlich ascites tumor cells, transformed monkey kidney cells, and human xeroderma pigmentosa cells (Darfler and Insel, 1983; Koch and Bigalow, 1979; Parshad et al., 1978; Sagone et al., 1984; Wang and Nixon, 1984). The requirement for catalase can become more apparent when the cells are cultured at low cell densities (Darfler and Insel, 1983). Our neuronal cultures that require catalase at low seeding densities become capable of self-support at higher seeding densities (Barbin et al., 1984b).

Enhanced survival of non-neuronal cell types in the presence of catalase has generally been attributed to protection from $\mathrm{H}_{2} \mathrm{O}_{2}$ contained in the culture medium itself (Darfler and Insel, 1983; Koch and Bigalow, 1979; Parshad et al., 1978; Sagone et al., 1984; Wang and Nixon, 1978). Culture medium alone generates $\mathrm{H}_{2} \mathrm{O}_{2}$ and organic peroxides, after exposure to light, through interaction of photoactivated riboflavin with tryptophan and tyrosine (Hoffman and Meneghini, 1979; Wang and Nixon, 1978). The concentrations of oxygen used in culture incubators have been suggested (Hornsby and Gill, 1981; Parshad et al., 1978 ) to provide a source of superoxide ions, which could in turn mediate the formation of peroxides. Although the mech- 
anisms of peroxide formation were not addressed here, we did demonstrate that our Hanks' modified Eagle's basal medium does contain peroxides even in the absence of the test neurons. Addition of catalase significantly reduced, though did not eliminate, the accumulation of peroxides, in agreement with previous findings using Dulbecco's modified Eagle's medium (Wang and Nixon, 1978).

Hydrogen peroxide and superoxide ion, the latter being converted to $\mathrm{H}_{2} \mathrm{O}_{2}$ by superoxide dismutase, are generated during a number of metabolic processes (Ramasarma, 1982). It seems likely that the cultured neurons might themselves generate $\mathrm{H}_{2} \mathrm{O}_{2}$ in addition to that produced by the medium. Such intracellular pools of peroxide could be particularly important in deciding cell viability. It is well known that lipid-soluble vitamin $\mathrm{E}$ ( $\alpha$-tocopherol) readily crosses cell membranes, and that HRP is taken up by neurons in a manner that allows retention of its enzymatic activity (LaVail and LaVail, 1974). These observations suggest the possibility of both intra- and extracellular sites of action in support of neuronal survival. Catalase and lactoperoxidase, however, may not be internalized by neurons (Bunt and Haschke, 1978; Malmgren et al., 1978; Nässel, 1983). The simplest hypothesis consistent with all the data is that catalase promotes neuronal survival by reducing culture medium peroxide levels. If so, its role would be one of improving the neuronal culture environment, and not of entertaining a direct neuronotrophic interaction with the nerve cells, as would be expected of a conventional "neuronotrophic factor."

Although this study failed to produce such a traditional neuronotrophic factor, it does have value in illuminating a common, though perhaps not widely appreciated, characteristic of the culture environment, namely, that of generating toxic peroxides. The serum-free conditions used are similar to those employed by a number of other laboratories, with the $\mathrm{N} 1$ additives of Bottenstein et al. (1980). Although serum-containing medium was not examined in these studies, reports in the literature indicate that it too generates peroxides (Hoffman and Meneghini, 1979; Parshad et al., 1978; Wang and Nixon, 1978). The presence of these toxic compounds is likely to complicate other studies of neuronal survival and growth in vitro, as well as studies of neuronal metabolism or membrane constituents in vitro. Routine inclusion of catalase in culture media could help to reduce peroxide-induced neuronal damage.

\section{References}

Aebi, H., S. R. Wyss, B. Scherz, and F. Skvaril (1974) Heterogeneity of erythrocyte catalase II. Isolation and characterization of normal and variant erythrocyte catalase and their subunits. Eur. J. Biochem. 48: $137-145$.

Amicon Corporation (1980) Dye-Ligand Chromatography: Applications, Method, Theory of Matrex Gel Media, Amicon Corporation, Lexington, MA.

Appel, S. (1981) A unifying hypothesis for the cause of amyotrophic lateral sclerosis, Parkinsonism and Alzheimer disease. Ann. Neurol. 10: 499-505.

Banker, G. A. (1980) Trophic interactions between astroglial cells and hippocampal neurons in culture. Science 209: 809-810.

Barbin, G., M. Manthorpe, and S. Varon (1984a) Purification of the chick eye Ciliary Neuronotrophic Factor (CNTF). J. Neurochem. 43: 1468-1478.

Barbin, G., I. Selak, M. Manthorpe, and S. Varon (1984b) Use of central neuronal cultures for the detection of neuronotrophic agents. Neuroscience 12: 33-43.

Barde, Y.-A., D. Fdgar, and H. Thoenen (1982) Purification of a new neurotrophic factor from mammalian brain. Eur. Mol. Biol. Org. J. 1: 549-553.

Barron, K. D. (1983) Comparative observations on the cytologic re actions of central and peripheral nerve cells to axotomy. In Spinal Cord Reconstruction, C. C. Kao, R. P. Bunge, and P. J. Rier, eds., pp. 7-40, Raven, New York.

Blakesley, R. W., and J. A. Boezi (1977) A new staining technique for proteins in polyacrylamide gels using Coomassie brilliant blue G250. Anal. Biochem. 82: 580-582.

Bottenstein, J. E., S. D. Skaper, S. Varon, and G. H. Sato (1980) Selective survival of neurons from chick embryo sensory ganglionic dissociates utilizing serum-free supplemented medium. Exp. Cell Res. 125: $183-190$.

Bradford, M. (1976) A rapid and sensitive method for the quantitation of microgram quantities of protein utilizing the principle of proteindye binding. Anal. Biochem. 72: 248-254.

Brannan, T. S., H. S. Maker, and I. P. Raes (1981) Regional distribution of catalase in the adult rat brain. J. Neurochem. 36: 307-309.

Bunt, A. H., and R. Haschke (1978) Features of foreign proteins affecting their retrograde transport in axons of the visual system. $J$. Neurocytol. 7: 665-678.

Cowan, W. M., J. W. Fawcett, D. D. M. O'Leary, and B. B. Stanfield (1984) Regressive events in neurogenesis. Science 225: 1258-1265.

Darfler, F. J., and P. A. Insel (1983) Clonal growth of lymphoid cells in serum-free media requires elimination of $\mathrm{H}_{2} \mathrm{O}_{2}$ toxicity. J. Cell Physiol. 115: 31-36.

Greene, L. A., and E. M. Shooter (1980) The nerve growth factor: Biochemistry, synthesis and mechanism of action. Annu. Rev. Neurosci. 3: 353-402.

Gurney, M. E., and B. Apatoff (1984) Activity of a muscle-derived growth factor for spinal neurons in vitro and in vivo. Soc. Neurosci. Abstr. 10: 1051.

Halks-Miller, M., J. P. Kane, J. H. Beckstead, and E. A. Smuckler (1982) Vitamin E-enriched lipoproteins increase longevity of neurons in vitro. Dev. Brain Res 2: 439-447.

Hennessey, M. A., A. M. Waltersdorph, F. M. IIuennekens, and B. W. Gabrio (1962) Erythrocyte metabolism. VI. Separation of erythrocyte enzymes from hemoglobin. J. Clin. Invest. 41: 1257-1262.

Hoffmann, M. E., and R. Meneghini (1979) DNA strand breaks in mammalian cells exposed to light in the presence of riboflavin and tryptophan. J. Photochem. Photobiol. 29: 299-303.

Hornsby, P. J., and G. N. Gill (1981) Regulation of glutamine and pyruvate oxidation in cultured adrenocortical cells by cortisol, antioxidants and oxygen: Effects on cell proliferation. J. Cell Physiol. 109: $111-120$.

Kaufman, L. M., and J. N. Barrett (1983) Serum factor supporting long-term survival of rat central neurons in culture. Science 220: 1394-1396.

Koch, C. J., and J. E. Bigalow (1979) Toxicity, radiation sensitivity modification, and metabolic effects of dehydroascorbate and ascorbate in mammalian cells. J. Cell Physiol. 94: 299-306.

LaVail, J. H., and M. M. LaVail (1974) The retrograde intraaxonal transport of horseradish peroxidase in the chick visual system: A light and electron microscopic study. J. Comp. Neurol. 157: 303-358.

Longo, F. M., I. Selak, J. Zovickian, M. Manthorpe, S. Varon, and H.S. U (1984) Neuronotrophic activities in cerebrospinal fluid of head trauma patients. Exp. Neurol. 84: 207-218.

Malmgren, L., Y. Olsson, T. Olsson, and K. Kristensson (1978) Uptake and retrograde axonal transport of various exogenous macromolecules in normal and crushed hypoglossal nerves. Brain Res. 153: 477-493.

Manthorpe, M., F. M. Longo, and S. Varon (1982) Comparative features of spinal neuronotrophic factors in fluids collected in vitro and in vivo. J. Neurosci. Res. 8: 241-250.

Manthorpe, M., E. Engvall, E. Ruoslahti, F. M. Longo, G. E. Davis, and S. Varon (1983a) Laminin promotes neuritic regeneration from cultured peripheral and central neurons. J. Cell Biol. 97: 1882-1890.

Manthorpe, M., M. Nieto-Sampedro, S. D. Skaper, E. R. Lewis, G. Barbin, F. M. Longo, C. W. Cotman, and S. Varon (1983b) Neuronotrophic activity in brain wounds of the developing rat. Correlation with implant survival in the wound cavity. Brain Res. 267: 47-56.

Manthorpe, M., S. D. Skaper, L. R. Williams, and S. Varon (in press) Purification of the adult rat sciatic nerve ciliary neuronotrophic factor. Brain Res.

Mörikofer-Zwez, S., M. Cantz, H. Kaufmann, J. P. von Wartburg, and H. Aebi (1969) Heterogenity of erythrocyte catalase: Correlations between sulfhydryl group content, chromatographic and electrophoretic properties. Eur. J. Biochem. 11: 49-57.

Müller, H. W., S. Beckh, and W. Seifert (1984) Neurotrophic factor for central neurons. Proc. Natl. Acad. Sci. USA 81: 1248-1252.

Nässel, D. R. (1983) Extensive labelling of injured insect neurons with seven different heme peptides. Histochemistry 79: 95-104. 
Nieto-Sampedro, M., E. R. Lewis, C. W. Cotman, M. Manthorpe, S. D. Skaper, G. Barbin, F. M. Longo, and S. Varon (1982) Brain injury causes a time-dependent increase in neuronotrophic activity at the lesion site. Science 217: 860-861.

Olofsson, T., and I. Olsson (1977) Purification of human granulocyte catalase in chronic myeloid leukemia. Biochim. Biophys. Acta 482: 301-308.

Ortiz de Montellano, P. R., and D. E. Kerr (1983) Inactivation of catalase by phenylhydrazine: Formation of a stable aryl-iron heme complex. J. Biol. Chem. 258: 10558-10563.

Parshad, R., K. K. Sanford, G. M. Jones, and R. E. Tarone (1978) Fluorescent light-induced chromosome damage and its prevention in mouse cells in culture. Proc. Natl. Acad. Sci. USA 75: 1830-1833.

Porumb, H., I. Lascu, D. Matinca, M. Oarga, V. Borza, M. Telia, O. Popescu, G. Jebeleanu, and O. Borzu (1982) Separation of erythrocyte enzymes from hemoglobin by chromatography on blue-Sepharose. FEBS Lett. 139: 41-44.

Ramasarma, T. (1982) Generation of $\mathrm{H}_{2} \mathrm{O}_{2}$ in biomembranes. Biochim. Biophys. Acta 694: 69-93.

Rudge, J. S., M. Manthorpe, and S. Varon (1985) The output of neuronotrophic and neurite-promoting agents from rat brain astroglial cells: A microculture method for screening potential regulatory molecules. Dev. Brain Res. 19: 161-172.

Sagone, A. L., R. Husney, H. Guter, and L. Clark (1984) Effect of catalase on the proliferation of human lymphocytes to phorbol myristate acetate. J. Immunol. 133: 1488-1494.

Schroeder, W. A., J. R. Shelton, J. B. Shelton, G. Apell, L. Evans, J.
Bonaventura, and R. S. Fang (1982) The partial amino acid sequence of human erythrocyte catalase. Arch. Biochem. Biophys. 214: 422424.

Selak, I., S. D. Skaper, and S. Varon (1985) Pyruvate participation in the low molecular weight trophic activity for central nervous system neurons in glia-conditioned media. J. Neurosci. 5: 23-28.

Shaltiel, S. (1974) Hydrophobic chromatography. Methods Enzymol. 34: 126-140.

Sinet, P. M., R. E. Heikkila, and G. Cohen (1980) Hydrogen peroxide production by rat brain in vivo. J. Neurochem. 34: 1421-1428.

Turner, J. E. (1985) Promotion of neurite outgrowth and cell survival in dissociated fetal rat retinal cultures by a fraction derived from a brain extract. Dev. Brain Res. 18: 265-274.

Varon, S., and R. Adler (1981) Trophic and specifying factors directed to neuronal cells. Adv. Cell. Neurobiol. 2: 115-163.

Varon, S., M. Manthorpe, and L. R. Williams (1984a) Neuronotrophic and neurite promoting factors and their clinical potentials. Dev. Neurosci. 6: 73-100.

Varon, S., S. D. Skaper, G. Barbin, I. Selak, and M. Manthorpe (1984b) Low molecular weight agents support survival of cultured neurons from the central nervous system. J. Neurosci. 4: 654-658.

Wang, R. J., and B. T. Nixon (1978) Identification of hydrogen peroxide as a photoproduct toxic to human cells in tissue-culture medium irradiated with "daylight" fluorescent light. In Vitro 14: 715-722.

Williams, L. R., I. Selak, S. D. Skaper, M. Manthorpe, and S. Varon (1985) CNS-directed neuronotrophic activity present in red blood cells. Brain Res. 336: 99-105. 